\title{
FAKTOR YANG MEMPENGARUHI KEPUTUSAN WISATAWAN MANCANEGARA MEMILIH PAKET VOLUNTOURISM DI IVHQ UBUD, BALI
}

\author{
Intan Permatasari Liyanti ${ }^{1}$, Ni Putu Eka Mahadewi ${ }^{2}$, I Gusti Putu Bagus Sasrawan Mananda ${ }^{3}$ \\ Email: intanpermatasari530@gmail.com¹, eka.mahadewi23@gmail.com², gusmananda@unud.ac.id ${ }^{3}$ \\ ${ }^{1,2,3}$ Program Studi Industri Perjalanan Wisata, Fakultas Pariwisata, Universitas Udayana
}

\begin{abstract}
The development of voluntourism in the world can be recognise from the existence of organizations that provide volunteer travel program. Bali as the icon of Indonesia tourism also become one of destination for voluntourism. Tourist that decide in choosing voluntourism package have its own tourist characteristic. With the presence of tourists who choose the voluntourism package, it is necessary to examine the factors that influence purchasing decisions and their dominant factors. The purpose of this study is to determine tourist characteristic, the factors and dominant factors that influence foreign tourist decision choosing voluntourism package in IVHq Ubud, Bali. Data collection in this research using questionnaire and distributed online by google form to user of volunteer program in IVHq Ubud with total sample of 44 respondents. Sampling technique in this research using purposive sampling. Data analysis technique using likert scale and factor analysis including validity test, and reliability test then the data processed by the Statistical Package for the Social Science (SPSS) version 18.0 program. The result of analysis factors show that there are five factors including image factors with eigen value of 6.040, external factor with eigen value of 2.378 , psychology with eigen value of 1.681, physical evidence factor with eigen value of 1.427 , and product factor dengan eigen value 1.025. The dominant factor infuencing foreign tourist decision choosing voluntourism package in IVHq Ubud, Bali is brand/image factor with eigen value of 6.040 .
\end{abstract}

Abstrak: Perkembangan voluntourism di dunia dapat terlihat dari adanya organisasi penyedia program perjalanan kegiatan volunteer. Bali yang merupakan ikon pariwisata Indonesia juga menjadi salah satu destinasi voluntourism. Wisatawan yang memilih untuk melakukan paket voluntourism memiliki karakteristik wisatawan tersendiri. Dengan adanya wisatawan yang memilih paket voluntourism maka perlu diteliti faktor-faktor yang mempengaruhi keputusan pembelian beserta faktor dominannya. Penelitian ini bertujuan untuk mengetahui karakteristik, faktor-faktor dan faktor dominan yang mempengaruhi keputusan wisatawan mancanegara memilih paket voluntourism di IVHq Ubud, Bali. Penelitian ini dilakukan dengan cara menyebarkan kuesioner secara online melalui media sosial kepada pengguna program volunteer IVHq Ubud dengan jumlah sampel 44 responden. Sampel penelitian ini dipilih menggunakan metode purposive sampling. Analisis data pada penelitian ini menggunakan skala likert dan analisis faktor termasuk uji validitas dan uji reliabilitas dimana data selanjutnya diolah dengan menggunakan program Statistical Package for the Social Science (SPSS) versi 18.0. Hasil analisis faktor mencakup dalam lima faktor yaitu faktor citra dengan eigen value sebesar 6.040, faktor eksternal dengan eigen value sebesar 2.378, faktor psikologis dengan eigen value sebesar 1.681, faktor bukti fisik dengan eigen value sebesar 1.427, dan faktor produk dengan eigen value 1.025. Faktor dominan yang mempengaruhi keputusan wisatawan mancanegara memilih paket voluntourism di IVHq Ubud, Bali adalah faktor citra dengan eigen value sebesar 6.040.

Keywords: voluntourism, factors affecting decision, voluntourist characteristic. 


\section{PENDAHULUAN}

Menurut buku "Volunteer Tourism: Theory Framework to Practical Application" dijelaskan hubungan antara volunteering dengan perjalanan berawal dari abad 19 ketika para misionaris, dokter dan guru melakukan perjalanan untuk membantu orang lain. Tetapi untuk beberapa orang, durasi lama tinggal dan persiapan yang intensif menjadi halangan untuk melakukan volunteering. Dengan berkembangnya volunteerism, perjalanan ini tidak lagi terbatas dan diminati oleh orang orang dengan pekerjaan tertentu melainkan orang - orang umum juga. Mereka mencari program yang sesuai dengan keadaan mereka yang akhirnya ditawarkan oleh tour operator. Adanya fenomena - fenomena dan trend dunia membawa perubahan dan munculnya inovasi baru dalam mengembangkan jenis kegiatan wisata. Berbagai macam istilah yang berkaitan dengan pariwisata terus bertambah seiring dengan perkembangan pariwisata dunia. Tidak heran dalam dunia pariwisata muncul istilah voluntourism.

Voluntourism berasal dari kata volunteer and tourism. Voluntourism sering dipromosikan sebagai suatu pengembangan pariwisata yang bermanfaat bagi destinasi wisata yang sejajar dengan pembangunan pariwisata berkelanjutan dengan menciptakan tempat yang lebih baik untuk hidup dan dikunjungi. Voluntourism adalah salah satu niche pasar pariwisata yang bertumbuh dengan cepat di dunia. Menurut International Volunteering: Trend and insight, industri volunteer travel ini mulai meningkat pada awal 2000an ketika biaya perjalanan pesawat terjangkau, terdapat kemudahan konektivitas dan online booking. Perkembangan sektor volunteer tourism dapat dilihat dari bertambahnya organisasi yang bergerak pada pasar ini dan pasar yang telah tersegmentasi, pasar tersebut yaitu individu, keluarga, kelompok, pelajar (khususnya pada jeda tahun), orang pada masa jeda karier dan perusahaan. Selain itu juga telah berkembang struktur penetapan harga misalnya proyek yang tidak dikenakan biaya walaupun peserta harus membayar tiket pesawat sendiri, proyek dengan biaya murah ataupun proyek yang dikenakan biaya oleh organisasi.

Menurut Tourism Research and Marketing (2008) organisasi, agensi dan fasilitator terbagi tiga kategori berdasarkan apakah mereka mengirim, menerima maupun penghubung peserta program volunteer. Organisasi pengirim secara umum berasal dari negara asal peserta program dan menyediakan informasi mengenai program dan idealnya bertanggung jawab untuk merekrut volunteer tourist (voluntourist) dan mengorganisasikan akomodasi, perjalanan, aktivitas waktu senggang, kebutuhan visa dan keuangan. Organisasi penerima adalah organisasi yang menerima peserta di komunitas dimana dilaksanakan kegiatan volunteer, menyediakan bimbingan dan instruksi tentang aktivitas volunteer, dan juga menyediakan kebutuhan yang berhubungan dengan kegiatan volunteer seperti pelatihan, materi bahan, instruksi keselamatan dan ansuransi. Organisasi penerima ada yang beroperasi dengan melakukan kerjasama bersama organisasi pengirim atau organisasi yang berdiri sendiri. Organisasi penghubung seperti goabroad bertindak sebagai perantara, mediator atau penyedia pihak ketiga yang merekrut, mengatur dan mendukung volunteers internasional melalui website mengenai program volunteer oleh organisasi pengirim atau penerima. Umumnya organisasi penghubung memiliki portal online yang menawarkan kesempatan voluntourism dimana dipasarkan berbagai aktivitas yang tersedia dari berbagai organisasi.

APEC Tourism Working Group report 2018 mendata organisasi yang berkaitan dengan program volunteer di wilayah APEC yang beranggotakan 21 negara. Berdasarkan data tersebut Indonesia termasuk salah satu negara tempat dilaksanakannya kegiatan voluntourism oleh organisasi Go Overseas dan Go Abroad. Organisasi penghubung ini termasuk organisasi yang mengumpulkan dan mempromosikan berbagai pengalaman dan program volunteer yang disediakan oleh berbagai organisasi di berbagai negara. Pada website goabroad.com terdapat daftar dengan 1129 organisasi yang menyediakan kesempatan volunteer secara Internasional. Goabroad.com merekomendasikan IVHq sebagai salah satu program untuk melakukan volunteer di Indonesia. Pada website gooverseas, IVHq termasuk 3 program teratas untuk kategori volunteer di Indonesia berdasarkan review terbanyak. Dengan mudahnya akses informasi secara online, informasi mengenai program volunteer yang disediakan oleh IVHq dapat dikenal dan diketahui oleh wisatawan yang berminat untuk melakukan kegiatan voluntourism. 
IVHq merupakan kategori organisasi pengirim untuk program volunteer dimana IVHq bekerjasama dengan Yayasan Green Lion dalam melaksanakan program volunteer di Bali. Yayasan Green Lion terletak di Desa Pejeng, Gianyar yang berdekatan dengan Ubud sebagai tempat pelaksanaan kegiatan. Ubud merupakan sebuah desa di Kabupaten Gianyar yang dikenal sebagai pusat seni dan budaya di Bali. Wisatawan yang tertarik mengikuti program volunteer ini dapat melakukan proses pemesanan secara online dan kemudian akan diberikan pengarahan secara lanjut.

Akan tetapi program IVHq memiliki harga yang tidak murah bagi wisatawan domestik dimana harga terendah untuk program IVHq Ubud selama seminggu adalah USD \$325 atau berkisar Rp. 4.806.157. Upah Minimum Provinsi (UMP) DKI Jakarta sebagai ibukota Indonesia pada tahun 2019 adalah sekitar Rp. 3.940.973. Jika membandingkan antara harga minimum program dengan UMP DKI Jakarta maka terlihat bahwa program volunteer di IVHq Ubud, Bali termasuk kategori yang lebih sulit menarik wisatawan domestik ditinjau dari pendapatannya. Oleh karena itu peserta program volunteer di IVHq Ubud, Bali kemungkinan besar lebih diminati oleh wisatawan mancanegara yang memiliki penghasilan yang lebih besar ataupun nilai mata uang yang lebih tinggi dari rupiah sehingga dapat melakukan pembelian paket dengan harga program tersebut.

Voluntourist atau wisatawan yang memilih kegiatan volunteer sambil berwisata memiliki karakteristik tersendiri yang dapat berbeda dengan jenis wisata lainnya. Ada beberapa penelitian yang mendata dan meneliti bagaimana karakteristik wisatawan yang melakukan voluntourism. Wisatawan yang datang mengunjungi Bali memiliki berbagai minat dan keinginan yang berbeda untuk dicapai pada masa liburannya. Dengan berbagai daya tarik dan kegiatan wisata, wisatawan dapat memilih jenis liburan yang diinginkannya. Adanya wisatawan yang memilih program volunteer khususnya di IVHq Ubud, Bali sebagai pilihan kegiatan wisatanya merupakan suatu fenomena yang menarik untuk diteliti lebih lanjut. Wisatawan yang melakukan perjalanan voluntourism pada program IVHq Ubud mungkin dapat memiliki karakteristik yang sama maupun berbeda dari hasil penelitian sebelumnya. Oleh karena itu maka perlu dilakukan penelitian mengenai karakteristik voluntourist, faktor-faktor yang mempengaruhi keputusan wisatawan mancanegara yang berkunjung ke Bali untuk berwisata sambil melakukan kegiatan volunteer, dan faktor paling dominan yang mempengaruhi di antara faktor lainnya. Dengan diketahuinya faktor tersebut dapat dijadikan acuan dalam pengembangan paket voluntourism yang ditawarkan oleh organisasi maupun perusahaan nirlaba. Melalui pengembangan paket voluntourism yang baik dapat memberikan dampak positif kepada destinasi yang dikunjungi serta komunitas dan kepada wisatawan itu sendiri. Hal tersebut akan mempengaruhi perkembangan pariwisata menjadi pariwisata yang bertanggung jawab.

\section{METODE}

Organisasi IVHq yang berpusat di Selandia Baru yang bekerjasama dengan organisasi lokal di Bali yaitu Yayasan Green Lion yang menjadi organisasi penerima dan menjadi tuan rumah dalam melaksanakan program volunteer di Ubud, Bali. dibutuhkan pelancong dan wisatawan. Penelitian ini mengutamakan pengumpulan data secara online menggunakan kuesioner berupa google form yang disebar melalui media sosial. Adapun sumber lain yang digunakan yaitu mencari unggahan pengguna paket volunteer di IVHq Ubud, Bali pada sosial media seperti Instagram, dan Facebook. Responden dalam penelitian ini nantinya akan diberikan tautan yang terhubung langsung ke kuesioner online tersebut.

Faktor-faktor awal yang digunakan pada penelitian ini untuk melihat faktor yang mempengaruhi keputusan memilih paket wisata voluntourism di IVHq Ubud, Bali terdiri atas 20 indikator yang tercakup dalam empat faktor. Adapun faktor-faktor dan indikator yang dimaksud antara lain faktor psikologis, faktor situasional, faktor sosial dan faktor bauran pemasaran yang terdiri dari Motivasi (X1), Persepsi (X2), Sikap (X3), Pembelajaran (X4), dan Kepribadian (X5), Sarana dan Prasarana (X6), Waktu Belanja (X7), Penggunaan Produk (X8), Kondisi Pembelian (X9), Peraturan/Undang-Undang (X10), Referensi (X11), Kelas Sosial (X12), Budaya (X13), Produk (X14), Harga (X15), Tempat (X16), Promosi (X17), Orang (X18), Bukti Fisik (X19), dan Proses (X20). Variabel faktor psikologis, situasional dan sosial diambil dari konsep faktor-faktor yang mempengaruhi keputusan pembelian oleh McKechnie dan 
konsep bauran pemasaran 7P dari Kotler dan Keller (2007).

Teknik pengumpulan data dilakukan dengan cara observasi non partisipasi kuesioner, studi pustaka dan dokumentasi. Dalam menentukan sampel pada penelitian ini digunakan rumus slovin dimana populasi diketahui melalui jumlah volunteer yang tergabung dalam grup IVHq Ubud di media sosial facebook sebanyak 4.233 orang yang telah berada selama 6 tahun. Karena keterbatasan dalam melakukan penelitian maka peneliti menentukan tingkat toleransi kesalahan atau $\mathrm{e}=15 \%$ dengan tingkat kepercayaan $85 \%$ sehingga minimal jumlah sampel penelitian adalah sebagai berikut: $\quad n=\frac{N}{1+N e^{2}}$

$$
\begin{aligned}
& n=\frac{4.233}{1+(4.233) 0.15^{2}} \\
& n=44
\end{aligned}
$$

Penelitian ini menggunakan teknik penentuan sampel purposive sampling yaitu teknik pengambilan data dengan pertimbangan tertentu. Alasan digunakan purposive sampling pada penelitian ini yaitu bertujuan agar data yang diperoleh nantinya bisa mewakili dan sesuai dengan kriteria yang ditentukan. Adapun kriteria yang dijadikan sampel pada penelitian ini yaitu wisatawan volunteer atau pengguna program IVHq di Ubud. Teknik analisis data digunakan dengan cara mengolah data melalui program Statistical Package for the Social Science SPSS versi 18.0 yang terdiri dari uji validitas, uji reliabilitas, analisis skala likert dan analisis faktor. Tahapan analisis faktor yaitu

1. Membuat matriks korelasi dengan uji KMO dan Uji MSA

2. Menentukan jumlah faktor

3. Rotasi faktor

4. Interpretasi faktor

\section{HASIL DAN PEMBAHASAN}

Karakteristik Wisatawan Mancanegara Pengguna Paket Volunteer IVHq Ubud, Bali

Karakteristik wisatawan mancanegara yang memilih paket voluntourism di IVHq Ubud, Bali didominasi wisatawan berjenis kelamin perempuan $(93,2 \%)$, sebagian besar berasal dari Negara Amerika Serikat (36,3\%), didominasi usia muda yaitu $17-25$ tahun $(77,2 \%)$, sebagian besar bekerja sebagai pelajar (59\%) dengan tingkat pendidikan sarjana $(43,2 \%)$, sebagian besar memiliki pendapatan $<\$ 1000 \quad(50 \%)$ dengan pengeluaran sebesar $\$ 470-\$ 530$ atau
\$745-\$795 (20,5\%). Berdasarkan jumlah keseluruhan pengalaman melakukan program volunteer didominasi oleh pemula atau baru pertama kali $(81,8 \%)$ sedangkan pengalaman melakukan volunteer di Ubud juga baru pertama kali (100\%). Berdasarkan lama tinggal lebih banyak yaitu $>1$ minggu $(36,5 \%)$ dimana biasanya program IVHq Ubud berlangsung minimal selama 5 hari, berdasarkan akomodasi wisatawan selama di Bali didominasi oleh rumah volunteer $(75 \%)$ sedangkan berdasarkan sumber informasi sebagian besar melalui website $(50 \%)$. Berdasarkan teori pemenuhan kebutuhan Maslow, wisatawan ingin melakukan program volunteer didominasi karena keinginan menjadi orang baik dan melakukan sesuatu yang berguna atau penolong yang termasuk kategori keinginan untuk dihargai (pencapaian, status, tanggung jawab, reputasi).

\section{Analisis Skala Kesesuaian Tanggapan Wisatawan}

Skala kesesuaian merupakan skala interval untuk mengukur pola tertentu seperti keputusan. Berdasarkan hasil penelitian ini maka skala likert digunakan sebagai metode untuk menganalisis hasil statistik menjadi bahasa deskriptif. Adapun hasilnya terlihat pada Tabel 1 berikut.

\begin{tabular}{|c|c|c|c|c|}
\hline No & Indikator & $\begin{array}{l}\text { Rata } \\
\text {-rata }\end{array}$ & $\begin{array}{l}\text { Keteranga } \\
\mathrm{n}\end{array}$ & $\begin{array}{l}\text { Kod } \\
\text { e }\end{array}$ \\
\hline \multirow[t]{3}{*}{1} & Motivasi & 4,57 & $\begin{array}{l}\text { Sangat } \\
\text { Setuju }\end{array}$ & $\mathrm{X} 1$ \\
\hline & $\begin{array}{l}\text { a. Motivasi } \\
\text { internal }\end{array}$ & 4,64 & $\begin{array}{l}\text { Sangat } \\
\text { Setuju }\end{array}$ & $\mathrm{X} 1.1$ \\
\hline & $\begin{array}{l}\text { b. Motivasi } \\
\text { eksternal }\end{array}$ & 4,50 & $\begin{array}{l}\text { Sangat } \\
\text { Setuju }\end{array}$ & $\mathrm{X} 1.2$ \\
\hline 2 & Persepsi & 3,86 & Setuju & $\mathrm{X} 2$ \\
\hline 3 & Sikap & 4,25 & $\begin{array}{l}\text { Sangat } \\
\text { Setuju }\end{array}$ & $\mathrm{X} 3$ \\
\hline \multirow[t]{3}{*}{4} & Pembelajaran & 2,64 & $\begin{array}{l}\text { Cukup } \\
\text { Setuju }\end{array}$ & $\mathrm{X} 4$ \\
\hline & $\begin{array}{l}\text { a.Pengalaman } \\
\text { pribadi }\end{array}$ & 1,70 & $\begin{array}{l}\text { Sangat } \\
\text { Tidak } \\
\text { Setuju }\end{array}$ & $\mathrm{X} 4.1$ \\
\hline & $\begin{array}{l}\text { b.Pengalaman } \\
\text { orang lain }\end{array}$ & 3,57 & Setuju & $\mathrm{X} 4.2$ \\
\hline \multirow[t]{3}{*}{5} & Kepribadian & 4,54 & $\begin{array}{l}\text { Sangat } \\
\text { Setuju }\end{array}$ & $\mathrm{X} 5$ \\
\hline & $\begin{array}{l}\text { a.Karakter } \\
\text { menolong }\end{array}$ & 4,50 & $\begin{array}{l}\text { Sangat } \\
\text { Setuju }\end{array}$ & $\mathrm{X} 5.1$ \\
\hline & $\begin{array}{l}\text { b.Keinginan } \\
\text { menolong saat } \\
\text { berwisata }\end{array}$ & 4,57 & $\begin{array}{l}\text { Sangat } \\
\text { Setuju }\end{array}$ & $\mathrm{X} 5.2$ \\
\hline 6 & $\begin{array}{l}\text { Sarana dan } \\
\text { Prasarana }\end{array}$ & 3,82 & Setuju & X6 \\
\hline
\end{tabular}

Tabel 1. Skala Likert Keputusan Wisatawan 


\begin{tabular}{llclc}
\hline 7 & Waktu & 3,77 & Setuju & X7 \\
\hline 8 & $\begin{array}{l}\text { Penggunaan } \\
\text { Produk }\end{array}$ & 3,68 & Setuju & X8 \\
\hline 9 & $\begin{array}{l}\text { Kondisi } \\
\text { Pembelian }\end{array}$ & 3.34 & $\begin{array}{l}\text { Cukup } \\
\text { Setuju }\end{array}$ & X9 \\
\hline 10 & $\begin{array}{l}\text { Peraturan / } \\
\text { undang-undang }\end{array}$ & 3,82 & Setuju & X10 \\
\hline 11 & Referensi & 2,55 & $\begin{array}{l}\text { Tidak } \\
\text { Setuju }\end{array}$ & X11 \\
\hline 12 & Kelas Sosial & 3,66 & Setuju & X12 \\
\hline 13 & Budaya & 2,70 & $\begin{array}{l}\text { Cukup } \\
\text { Setuju }\end{array}$ & X13 \\
\hline 14 & Product & 4,36 & $\begin{array}{l}\text { Sangat } \\
\text { Setuju }\end{array}$ & X14 \\
\hline 15 & Price & 3,41 & Setuju & X15 \\
\hline 16 & Place & 3,52 & Setuju & X16 \\
\hline 17 & Promotion & 2,66 & Cukup & X17 \\
& & 3,93 & Setuju & X18 \\
\hline 18 & People & 4,05 & Setuju & X19 \\
\hline 19 & $\begin{array}{l}\text { Physical } \\
\text { evidence }\end{array}$ & 4,02 & Setuju & X20 \\
\hline 20 & Process & 4,24 & Sangat Setuju \\
\hline Rata-rata Total & Prasil pencen & & \\
\hline
\end{tabular}

Sumber: Hasil penelitian 2020.

Berdasarkan Tabel 1 dapat dilihat keputusan wisatawan mancanegara yang memilih paket voluntourism IVHq di Ubud, Bali menurut skala interval keputusan. Keputusan wisatawan menurut jawaban dari hasil kuesioner wisatawan adalah indikator motivasi internal (X1.1) sebagai keputusan tertinggi wisatawan memilih paket volunteer dengan skor 4,64 dalam kategori sangat setuju sehingga dapat dijelaskan keputusan mancanegara lebih termotivasi untuk pemenuhan kebutuhan pribadi yang mereka inginkan. Sedangkan keputusan terendah wisatawan adalah indikator pembelajaran pengalaman pribadi (X4.1) dengan skor 1,70 dalam kategori sangat tidak setuju. Hal ini dikarenakan menurut hasil kuesioner kebanyakan responden baru pertama kali melakukan program volunteer dan semua responden menjawab baru pertama kali melakukan program volunteer IVHq di Ubud, Bali sehingga pembelajaran pengalaman pribadi menjadi pilihan terendah yang membuat responden memutuskan untuk memilih paket voluntourism di IVHq Ubud, Bali.

\section{Uji Validitas}

Uji Validitas merupakan pengujian yang digunakan untuk menguji valid tidaknya suatu instrumen yang digunakan dalam penelitian. Instrumen tersebut dikatakan valid apabila koefisiennya melebihi $0,361(\mathrm{df}=\mathrm{n}-\mathrm{k}$, dengan Sig 5\%). Uji validitas dapat dilakukan dengan melihat korelasi antara skor masingmasing item dalam kuesioner dengan total skor yang ingin diukur. Jika $\mathbf{r}$ hitung > r tabel 0,361 $\{\mathrm{df}=30-2$ (28) dengan Sig 5\% $\}$ dapat dilihat pada tabel $\mathrm{r}$, maka pengukuran tersebut valid. Namun apabila $\mathbf{r}$ hitung $<\mathbf{r}$ table maka pengukuran tersebut tidak valid (Ghozali 2005). Perhitungan uji validitas ini dilakukan dengan Program SPSS 18.0 for windows. Dalam penelitian ini seluruh indikator yang duji validitas dapat dikatakan valid, dari 20 variabel yang diuji tersebut semua variabel memiliki nilai lebih dari 0.361 , karena semua variabel tersebut valid, maka akan digunakan dalam pengujian selanjutnya yaitu uji reliabilitas dan analisis data.

\section{Uji Reliabilitas}

Pengujian reliabilitas ini digunakan untuk melakukan pengujian terhadap hasil dari jawaban kuesioner yang telah dilakukan, dan untuk menguji apakah hasil penelitian reliabel atau tidak. Jadi apabila instrument tersebut digunakan beberapa kali untuk mengukur objek yang sama, akan menghasilkan hasil yang sama. hasil uji reliabilitas terhadap 30 responden yang dijadikan sampel didapatkan hasil bahwa nilai Cronbach's Alpha adalah sebesar 0,856 dimana nilai ini dikatakan telah memenuhi syarat atau reliable, karena nilainya lebih dari 0,6. Hal ini menunjukkan bahwa kuesioner yang telah diuji dapat memberikan hasil yang konsisten bila nantinya dilakukan pengujian atau pengukuran kembali.

\section{Analisis Faktor}

\section{Membuat Matriks Korelasi}

Matriks korelasi

dapat mengidentifikasikan variabel - variabel mana saja yang terkait satu sama lain dan saling berhubungan dari ke-20 variabel yang dianalisis. Untuk menguji hal tersebut, maka dilakukan langkah - langkah yang terdiri dari uji KMO, dan uji MSA.

a. Uji Kaiser-Meyer - Olkin (KMO)

Berdasarkan hasil olah data SPSS maka nilai KMO yang diperoleh sebesar 0,596 yang berarti angka ini menunjukkan syarat kecukupan yang sudah melebihi 0,5 dan memenuhi kriteria untuk dilakukan proses ke langsung selanjutnya.

b. Uji Measure of Sampling Adequacy (MSA) 
Uji MSA dilakukan untuk mengukur derajat korelasi antar variabel, dimana setiap variabel dianalisis untuk mengetahui variabel mana yang layak untuk diproses lebih lanjut dan mana yang harus dikeluarkan. Variabel yng valid dapat diproses lebih lanjut, yaitu jika nilai MSA pada setiap variabel $>0,5$. Berdasarkan hasil olah data dari 20 indikator yang ada, terdapat dua indikator yang memiliki nilai kurang dari 0,5 dengan hasil ini maka dua indikator yaitu $\mathrm{x} 9$ dan $\mathrm{x} 13$ akan dikeluarkan dari analisis selanjutnya dan 18 indikator digunakan karena memenuhi persyaratan nilai standar dari MSA > 0,5 sehingga dapat dikatakan memenuhi syarat nilai standar dari MSA dan dapat digunakan pada analisis selanjutnya.

\section{Menentukan Jumlah Faktor}

Penentuan jumlah faktor dilakukan untuk menentukan berapa banyak faktor yang terbentuk yang mewakili variabel-variabel. Penentuan jumlah faktor ini berdasarkan pada besarnya eigenvalue setiap faktor yang muncul. Semakin besar eigenvalue setiap faktor, semakin representatif faktor tersebut untuk mewakili sekelompok variabel. Faktor-faktor inti yang dipilih adalah faktor yang mempunyai eigenvalue $\geq 1$. Hasil penentuan jumlah faktor tersaji secara rinci pada Tabel 2.

Tabel 2 Total Variance Explained

\begin{tabular}{rrrr}
\hline Component & \multicolumn{3}{c}{ Initial Eigenvalues } \\
\cline { 2 - 4 } & Total & $\begin{array}{c}\text { \% of } \\
\text { Variance }\end{array}$ & $\begin{array}{c}\text { Cumulative } \\
\%\end{array}$ \\
\hline 1 & 6.04 & 33.556 & 33.556 \\
\hline 2 & 2.38 & 13.214 & 46.77 \\
\hline 3 & 1.68 & 9.337 & 56.107 \\
\hline 4 & 1.43 & 7.926 & 64.033 \\
\hline 5 & 1.03 & 5.696 & 69.73 \\
\hline 6 & 0.95 & 5.263 & 74.992 \\
\hline 7 & 0.78 & 4.334 & 79.326 \\
\hline 8 & 0.67 & 3.712 & 83.038 \\
\hline 9 & 0.62 & 3.433 & 86.471 \\
\hline 10 & 0.53 & 2.93 & 89.401 \\
\hline 11 & 0.42 & 2.305 & 91.706 \\
\hline 12 & 0.38 & 2.082 & 93.788 \\
\hline 13 & 0.33 & 1.809 & 95.597 \\
\hline 14 & 0.24 & 1.317 & 96.914 \\
\hline 15 & 0.19 & 1.069 & 97.983 \\
\hline & & &
\end{tabular}

\begin{tabular}{rrrr}
\hline 16 & 0.17 & 0.919 & 98.902 \\
\hline 17 & 0.12 & 0.638 & 99.54 \\
\hline 18 & 0.08 & 0.46 & 100 \\
\hline
\end{tabular}

Sumber: Hasil penelitian 2020

Dalam tahap ini terbentuk lima faktor dari 20 indikator yang mempengaruhi keputusan wisatawan mancanegara memilih Paket Voluntourism di IVHq Ubud, Bali. Kelima faktor tersebut memiliki eigenvalue $>1$, yaitu $6.040,2.378,1.681,1.427$ dan 1.025 dengan nilai Cumulative eigenvalue sebesar $69,730 \%$. Berdasarkan pada nilai percent of variance, diketahui bahwa faktor yang menyumbangkan bagian variasi terbesar dari keseluruhan yang dianalisa adalah faktor ke-1 yaitu sebesar 33,556\%. Dengan demikian dapat diketahui bahwa faktor yang terbentuk menjelaskan $69,730 \%$ total varian variabel yang mempengaruhi keputusan wisatawan mancanegara memilih paket voluntourism di IVHq Ubud, Bali.

\section{Rotasi Faktor}

Rotasi faktor merupakan langkah yang dilakukan untuk menyederhanakan matrik faktor itu sendiri. Matrik faktor yang terbentuk masih diidentifikasi, sehingga perlu dilakukannya rotasi faktor untuk menunjukkan hasil yang terstruktur dan lebih sederhana. Dengan cara ini dapat mempermudah penjelasan seluruh faktor yang dianalisis dalam model. Metode penelitian yang dipergunakan dalam penelitian ini adalah rotasi dengan metode varimax. Rotasi varimax dipilih karena memberikan hasil yang lebih mudah dianalisa secara teori. Hasil dari rotasi varimax dapat dilihat pada Tabel 3 berikut.

Tabel 3 Rotasi Faktor 
Rotated Component Matrix ${ }^{\mathrm{a}}$

\begin{tabular}{l|r|r|r|r|r}
\hline & \multicolumn{5}{|c}{ Component } \\
\cline { 2 - 6 } & \multicolumn{1}{|c|}{1} & \multicolumn{1}{|c}{2} & \multicolumn{1}{c}{. } & \multicolumn{1}{c}{5} \\
\hline $\mathrm{X} 1$ & .557 & .232 & -.032 & .266 & .489 \\
$\mathrm{X} 2$ & .403 & .068 & .715 & .232 & -.127 \\
$\mathrm{X} 3$ & .291 & .201 & .848 & -.069 & -.050 \\
$\mathrm{X} 4$ & .401 & .435 & .324 & .303 & -.484 \\
$\mathrm{X} 5$ & .699 & .138 & .197 & .123 & .000 \\
$\mathrm{X} 6$ & -.012 & .193 & .792 & .179 & .216 \\
$\mathrm{x} 7$ & .265 & -.153 & .543 & .386 & .403 \\
$\mathrm{x} 8$ & .659 & -.280 & .067 & .241 & .151 \\
$\mathrm{x} 10$ & .807 & .015 & .136 & -.030 & -.054 \\
$\mathrm{x} 11$ & .555 & .207 & .156 & .200 & -.131 \\
$\mathrm{x} 12$ & .312 & .574 & .020 & .065 & .404 \\
$\mathrm{x} 14$ & -.023 & .152 & .124 & .183 & .809 \\
$\mathrm{x} 15$ & -.079 & .831 & .173 & .053 & .119 \\
$\mathrm{x} 16$ & .054 & .886 & -.002 & .216 & .001 \\
$\mathrm{x} 17$ & .189 & .811 & .204 & .097 & .005 \\
$\mathrm{x} 18$ & .059 & .358 & .177 & .751 & .139 \\
$\mathrm{x} 19$ & .292 & .094 & .125 & .828 & .128 \\
$\mathrm{x} 20$ & .591 & .247 & .267 & .018 & .318 \\
\hline
\end{tabular}

Extraction Method: Principal Component

Analysis.

Rotation Method: Varimax with Kaiser

Normalization.

a. Rotation converged in 6 iterations.

Sumber: Hasil penelitian 2020

Berdasarkan Tabel 3 hasil analisis rotasi maka dapat dipaparkan bahwa dari ke 18 indikator yang telah dirotasi, terdapat 17 yang memenuhi syarat atau kriteria dan terdapat 1 indikator yang tidak memenuhi kriteria dikarenakan loading factor yang tidak mencapai 0,5. Indikator yang dimaksud adalah Pembelajaran (X4). Hasil ini sesuai dengan hasil penilaian skala interval likert dimana pembelajaran juga mendapat skor rendah yaitu 2,64 dengan keterangan cukup setuju. Dengan menggunakan metode Principal Componen Analisis (PCA) maka variabel yang tersisa tersebar dalam lima faktor yang merupakan faktor-faktor yang mempengaruhi keputusan wisatawan mancanegara memilih paket voluntourism di IVHq Ubud, Bali. Adapun komponen variabel yang masuk ke dalam faktor yang pertama terdiri dari Motivasi (X1), Kepribadian (X5), Penggunaan Produk (X8), Peraturan / Undang - Undang (X10), Referensi (X11), dan Process (X20). Variabel yang lainnya masuk ke faktor yang kedua terdiri dari Kelas Sosial (X12), Price (X15), Place (X16), dan Promotion (X17). Variabel selanjutnya masuk ke dalam faktor yang ketiga yaitu Persepsi (X2), Sikap (X3), Sarana dan Prasarana (X6), dan Waktu (X7). Variabel selanjutnya masuk ke dalam faktor yang keempat yaitu People (X18), dan Physical Evidence ( X19). Variabel terakhir masuk ke dalam faktor yang kelima yaitu Product (X14).

\section{Interpretasi Faktor}

Interpretasi faktor dilakukan dengan cara mengelompokan variabel yang memiliki loading factor (korelasi) minimal memiliki nilai 0,5 sedangkan variabel yang memiliki nilai $<0,5$ maka variabel tersebut dikeluarkan dari model. (Hair et al, 2010). Pada penelitian ini terdapat satu variabel yang dikeluarkan atau dieliminasi karena kurang atau berada dibawah dari nilai loading factor 0,5 yaitu variabel Pembelajaran (X4). Berdasarkan hasil tersebut, maka dapat diketahui dari jumlah total 20 variabel yang dianalisa hanya terdapat 17 variabel yang berada pada angka loading factor $>0,5$ yang tergabung dalam lima faktor. Pada tahapan ini faktor yang merupakan gabungan dari suatu variabel harus diberi nama. Pemberian nama harus mengacu pada variabelvariabel yang membentuk faktor yang bersangkutan atau berdasarkan pada variabel yang mempunyai loading faktor tertinggi dibandingkan variabel lain yang berada dalam satu faktor tersebut. Hasil interpretasi faktor dapat dilihat pada Tabel 4.

Faktor pertama diberi nama yaitu faktor citra dengan variabel yang memiliki factor loading tertinggi yaitu variabel peraturan / undang-undang dengan nilai 0,807. Faktor citra dalam penelitian ini terdiri dari atas 6 variabel yaitu Motivasi (X1), Kepribadian (X5), Penggunaan Produk (X8), Peraturan / Undang - Undang (X10), Referensi (X11), dan Process (X20). Faktor pertama diberi nama faktor citra dikarenakan citra baik yang terbentuk dari paket voluntourism yang memiliki peraturan yang jelas dan menjamin pelaksanaan program voluntourism, informasi referensi yang didapatkan dari lingkungan wisatawan dan proses informasi mengenai paket voluntourism yang mudah didapatkan dan kemudahan melakukan pemesanan paket. Selain itu motivasi dan kepribadian mempengaruhi keputusan wisatawan untuk melakukan voluntourism dikarenakan keinginan untuk menjadi orang baik dan menolong orang lain bahkan di saat berwisata. Motivasi dan kepribadian ini didukung oleh hasil kuesioner mengenai Teori Pemenuhan Kebutuhan Maslow yaitu responden memilih keinginan penghargaan (pencapaian, status, 
tanggung jawab, reputasi) sebagai orang baik dan penolong. sebesar $75 \%$ dari keseluruhan. berbeda dapat mempengaruhi keputusan pembelian terhadap paket voluntourism.

Tabel 4 Faktor-Faktor Yang Mempengaruhi Keputusan Wisatawan Mancanegara Memilih Paket Voluntourism Di IVHq Ubud, Bali Faktor-Faktor Yang Mempengaruhi Keputusan Wisatawan Mancanegara Memilih Paket Voluntourism Di IVHq Ubud, Bali

\begin{tabular}{|c|c|c|c|c|c|}
\hline No & Nama Faktor & Nama Variabel & $\begin{array}{l}\text { Eigen } \\
\text { value }\end{array}$ & $\begin{array}{l}\text { Loading } \\
\text { Faktor }\end{array}$ & $\begin{array}{c}\text { Persentase } \\
\text { Variance }\end{array}$ \\
\hline \multirow[b]{6}{*}{1} & \multirow[b]{6}{*}{ Faktor Citra } & Peraturan/ undang-undang (X10) & \multirow[b]{6}{*}{6,040} & 0,807 & \multirow[b]{6}{*}{$33,556 \%$} \\
\hline & & Kepribadian (X5) & & 0,699 & \\
\hline & & Penggunaan Produk (X8) & & 0,659 & \\
\hline & & Process (X20) & & 0,591 & \\
\hline & & Motivasi (X1) & & 0,557 & \\
\hline & & Referensi (X11) & & 0,555 & \\
\hline \multirow[b]{4}{*}{2} & \multirow{4}{*}{$\begin{array}{l}\text { Faktor } \\
\text { Eksternal }\end{array}$} & Place X16) & \multirow[b]{4}{*}{2,378} & 0,865 & \multirow[b]{4}{*}{$13,214 \%$} \\
\hline & & Price (X15) & & 0,801 & \\
\hline & & Promotion (X17) & & 0,590 & \\
\hline & & Kelas Sosial (X12) & & 0,574 & \\
\hline \multirow[b]{4}{*}{3} & \multirow{4}{*}{$\begin{array}{c}\text { Faktor } \\
\text { Piskologis }\end{array}$} & Sikap (X3) & \multirow[b]{4}{*}{1,681} & 0,848 & \multirow[b]{4}{*}{$9,337 \%$} \\
\hline & & Sarana dan Prasarana (X6) & & 0,792 & \\
\hline & & Persepsi (X2) & & 0,715 & \\
\hline & & Waktu (X7) & & 0,543 & \\
\hline \multirow[b]{2}{*}{4} & \multirow{2}{*}{$\begin{array}{c}\text { Faktor } \\
\text { Bukti Fisik }\end{array}$} & Physical evidence (X19) & \multirow[b]{2}{*}{1,427} & 0,828 & \multirow[b]{2}{*}{$7,926 \%$} \\
\hline & & People X18) & & 0,751 & \\
\hline 5 & Faktor Produk & Product (X14) & 1,025 & 0,809 & $5,696 \%$ \\
\hline
\end{tabular}

Sumber: Hasil penelitian 2020

Keinginan penghargaan ini menurut

Teori Maslow kategori penghargaan mencakup kebutuhan akan perasaan puas dan gengsi dengan dihargai oleh orang lain dan perasaan telah berkontribusi kepada dunia. Hasil ini didukung oleh penelitian Wright (2013) yang menyimpulkan bahwa altruisme atau keinginan menolong bukan salah satu motivasi utama untuk melakukan kegiatan volunteer. Penelitian Han dan Lee (2020) yang meneliti perilaku altruistik dari volunteer traveler dengan hasil penelitian yaitu pemenuhan keinginan pribadi (self interest desire) berkaitan signifikan terhadap perilaku altruistik atau menolong.

Faktor kedua yaitu faktor eksternal yang terdiri dari atas variabel Kelas Sosial (X12), Price (X15), Place (X16), dan Promotion (X17). Pemberian nama faktor eksternal dikarenakan variabel yang memiliki factor loading tertinggi yaitu variabel Place (X16) dengan nilai 0,865. Faktor Eksternal seperti tempat lokasi pelaksanaan program voluntourism, harga yang jelas dan promosi kegiatan yang tersebar melalui website, dan program voluntourism yang bisa diikuti oleh wisatawan dengan tingkat kelas sosial yang
Faktor ketiga diberi nama yaitu faktor psikologis dikarenakan variabel yang memiliki factor loading tertinggi yaitu variabel sikap (X3) dengan nilai 0,848 . Faktor psikologis dalam penelitian ini terdiri dari 4 variabel yaitu Persepsi (X2), Sikap (X3), Sarana dan Prasarana (X6), dan Waktu (X7). Faktor psikologis diambil dari konsep Mckechnie dimana psikologis seseorang mempengaruhi dalam pengambilan keputusan dan pembelian. Sikap perasaan dan pengetahuan mengenai kegiatan pada program voluntourism serta persepsi yang terbentuk dari citra organisasi dalam melaksanakan program dapat mempengaruhi keputusan pembelian wisatawan mancanegara terhadap paket voluntourism oleh IVHq Ubud, Bali.

Faktor keempat diberi nama yaitu faktor bukti fisik dikarenakan variabel Physical Evidence (X19) memiliki nilai loading factor terbesar yaitu 0,828. Faktor ini terdiri dari atas variabel People (X18), dan Physical Evidence (X19) dimana kesesuaian bukti fisik dengan produk yang ditawarkan serta pelayanan yang diberikan oleh pekerja lokal dapat mempengaruhi keputusan pembelian paket voluntourism. 
Faktor kelima yaitu faktor produk yang hanya terdiri dari variabel Product (X14). Bagaimana suatu produk dikemas, variasi jenis produk dan kesesuaian antara produk yang ditawarkan dengan pemenuhan kebutuhan dan keinginan seseorang dan dapat mempengaruhi keputusan pembelian.

\section{Analisis Faktor Dominan}

Berdasarkan hasil penelitian maka yang menjadi faktor paling dominan yaitu faktor citra. Faktor ini terdiri dari enam variabel yaitu: (1) peraturan/undang-undang, (2) Kepribadian, (3) Penggunaan Produk, (4) Proses, (5) Motivasi, (6) Referensi. Faktor citra mengungguli faktor lain dengan persentase variance $33,556 \%$ dan nilai eigenvalue sebesar 6,040 . Faktor Citra ini terbentuk dari gabungan beberapa faktor awal yaitu 2 variabel dari faktor sosial, 2 variabel dari faktor psikologis dan 1 variabel dari faktor bauran pemasaran. Setelah analisis faktor dilakukan terdapat perubahan posisi faktor dimana faktor yang terbentuk berbeda dengan variabel dari faktor sebelumnya. Hasil skala likert menunjukkan Variabel Motivasi sebagai variabel tertinggi yang mempengaruhi keputusan wisatawan dengan Variabel Kepribadian di posisi kedua. Hal ini menunjukkan kesesuaian hasil analisis skala likert dengan analisis faktor dimana faktor baru yang terbentuk diberi nama faktor citra terdiri dari variabel motivasi dan kepribadian sebagai salah satu variabel dari faktor citra yang menjadi faktor dominan yang mempengaruhi keputusan wisatawan.

Faktor citra menjadi bahwa faktor dominan yang mempengaruhi keputusan wisatawan mancanegara memilih paket voluntourism di IVHq Ubud, Bali antara lain karena adanya citra paket voluntourism memiliki program yang aman dengan adanya peraturan yang jelas dan menjamin wisatawan dalam melaksanakan voluntourism, proses pemesanan paket yang mudah dan kemudahan informasi mengenai paket yang bisa didapatkan melalui website dan internet membawa citra paket voluntourism jelas dan dapat dipercaya serta referensi atau masukan dari grup yang dimiliki seperti teman, keluarga ataupun orang lain mengenai voluntourism dapat menciptakan citra baik mengenai program dan kegiatan volunteer sambil berwisata. Menurut hasil kuesioner Teori Pemenuhan Kebutuhan Maslow, penulis berargumen bahwa motivasi dan kepribadian atau karakter wisatawan yang ingin melakukan sesuatu yang baik atau berguna sambil melakukan perjalanan wisata dipengaruhi oleh keinginan untuk diakui atau mendapat reputasi yang baik sehingga paket voluntourism yang menawarkan kegiatan wisata dan kegiatan volunteer dapat menjsdi pilihan yang tepat untuk memenuhi kebutuhan dan keinginan wisatawan, Hal ini didukung oleh penelitian Wright (2013) yang menyimpulkan bahwa altruisme atau keinginan menolong bukan salah satu motivasi utama untuk melakukan kegiatan volunteer dan bisa berbentuk suatu keegoisan atau suatu bentuk kepedulian. Penelitian Han dan Lee (2020) yang meneliti perilaku altruistik dari volunteer traveler dengan hasil penelitian yaitu pemenuhan keinginan pribadi (self interest desire) berkaitan signifikan terhadap perilaku altruistik atau menolong.

\section{SIMPULAN DAN SARAN Simpulan}

Berdasarkan hasil analisis data, faktor yang mempengaruhi keputusan wisatawan mancanegara memilih paket voluntourism di IVHq Ubud, Bali terdapat lima faktor yaitu faktor pertama yaitu faktor citra yang terdiri dari atas Motivasi (X1), Kepribadian (X5), Penggunaan Produk (X8), Peraturan / Undang - Undang (X10), Referensi (X11), dan Process (X20). Faktor Eksternal yang terdiri atas Kelas Sosial (X12), Price (X15), Place (X16), dan Promotion (X17). Faktor ketiga yaitu Faktor Psikologis yang terdiri atas Persepsi (X2), Sikap (X3), Sarana dan Prasarana (X6), dan Waktu (X7). Faktor keempat yaitu Faktor bukti fisik yang terdiri atas People (X18), dan Physical Evidence (X19) dan faktor kelima yaitu Faktor produk (X14).

Faktor dominan yang mempengaruhi keputusan wisatawan mancanegara memilih paket voluntourism di IVHq Ubud, Bali yaitu faktor citra mengungguli dari faktor lain dengan persentase variance $33,556 \%$ dan nilai eigenvalue sebesar 6,040.

\section{Saran}

Kepada organisasi penyedia paket voluntourism diharapkan lebih memperhatikan karakteristik wisatawan dalam mengembangkan perjalanan wisata dan program volunteer yang ditawarkan, serta memperhatikan factor-faktor yang dapat mempengaruhi keputusan konsumen melakukan pembelian paket voluntourism di Ubud, Bali. Mengetahui hal tersebut organisasi 
penyedia paket voluntourism di Bali perlu mengetahui trend yang sedang ada agar dapat mengemas produk paket voluntourism yang dapat menarik seperti wisatawan laki-laki dengan mengemas paket voluntourism yang lebih menantang, berat atau berpetualang ke pedalaman dan merangkul tempat tersebut sebagai destinasi baru untuk voluntourism. Promosi paket voluntourism juga sebaiknya dapat menjangkau berbagai negara selain Amerika Serikat dengan harga dan produk paket voluntourism yang menarik wisatawan dan juga bermanfaat bagi masyarakat lokal. Selain itu juga perlu untuk terus menjaga citra dari paket voluntourism yang ditawarkan agar tetap sesuai dengan prinsip pembangunan berkelanjutan dan nilai dari kegiatan volunteer sehingga dapat meminimalkan dampak negatif yang dapat timbul dari pengembangan voluntourism ke arah komersial.

Penelitian ini memiliki keterbatasan seperti data voluntourist yang diteliti hanya berasal dari satu organisasi dengan jenis privat atau milik swasta. sehingga hasil penelitian dapat berbeda dengan jenis voluntourist dari Non Goverment Organisation (NGO) dan nonprofit. Saran bagi peneliti selanjutnya agar dapat meneliti voluntourist dari berbagai organisasi, menggunakan teknik penelitian kualitatif untuk memperdalam dan membandingkan hasil penelitian ini dengan penelittian selanjutnya atau teknik kuantitatif dengan jumlah sampel yang lebih besar dengan menambah konsep motivasi sehingga menemukan lebih lanjut kesesuaian argumen pada penelitian ini dan hasil penelitian selanjutnya. 


\section{Kepustakaan}

APEC. 2018. Volutourism Best Practices: Promoting Inclusive Commnunity Based Sustainable Tourism Initiatives. https://www.apec.org//media/APEC/Publications/2018/5/Fin al-Report---Voluntourism-BestPractices-in-the-APECRegion/218_TWG_VoluntourismBest-Practices-in-the-APECRegion_Final-Report.pdf

Benson, Angela M. 2011. Volunteer Tourism Theory Framework to Practical Applications. Oxon: Routledge.

Han \& Lee. 2020. Tourism and Altruistic Intention: Volunteer Tourism Development and Self Interested Value. MDPI.

Kotler, Philip dan Keller. 2007. Manajemen Pemasaran, Jilid I, Edisi Kedua belas. Jakarta: PT. Indeks.

Maslow, Abraham H. 2002. Motivation and Personality. Harper \& Raw Publisher.

Sangadji, E.M., dan Sopiah. 2013. Perilaku Konsumen Pendekatan Praktis Pedoman Penelitian Disertai Himpunan Jurnal Penelitian. Yogyakarta: Penerbit Andi.

Tourism Research and Marketing. 2008. Report on Volunteer Tourism: A Global Analysis: Atlas.

Wright, Hayley. 2013. Volunteer Tourism and its (mis)perceptions: A comparative analysis of tourist/host perceptions Vol.13(4) 239-250, UK. 